$1-1-1960$

\title{
Rural development problems and prospects in Fayette, Raleigh, and Summers counties, West Virginia
}

William H. Metzler

W.W. Armentrout

Follow this and additional works at: https://researchrepository.wvu.edu/ wv_agricultural_and_forestry_experiment_station_bulletins

\section{Digital Commons Citation}

Metzler, William H. and Armentrout, W. W., "Rural development problems and prospects in Fayette, Raleigh, and Summers counties, West Virginia" (1960). West Virginia Agricultural and Forestry Experiment Station Bulletins. 444.

https://researchrepository.wvu.edu/wv_agricultural_and_forestry_experiment_station_bulletins/420 @ WVU. It has been accepted for inclusion in West Virginia Agricultural and Forestry Experiment Station Bulletins by an authorized administrator of The Research Repository @ WVU. For more information, please contact ian.harmon@mail.wvu.edu. 

Digitized by the Internet Archive in 2010 with funding from

Lyrasis Members and Sloan Foundation 


\title{
RURAL DEVELOPMENT PROBLEMS AND PROSPECTS
}

In Fayette, Raleigh, and Summers Counties, West Virginia

\author{
WEST VIRGINIA UNIVERSITY \\ AGRICULTURAL EXPERIMENT STATION \\ in cooperation with \\ Farm Economics Research Division \\ Agricultural Research Service \\ United States Department of Agriculture
}


West Virginia University

Agricultural Experiment Station

College of Agriculture, Forestry, and Home Economics

A. H. VanLandingham, Director

MORGANTOWN 


\section{RURAL DEVELOPMENT PROBLEMS AND PROSPECTS}

\section{In Fayette, Raleigh, and Summers Counties, West Virginia}

WILLIAM H. METZLER and W. W. ARMENTROUT ${ }^{1}$

THE three-county area around Beckley, West Virginia-Fayette, Raleigh, and Summers counties-has been selected as one of many experimental, or pilot, areas in the United States in which intensive analyses will be made and programs developed to build up the income levels of the rural people. This is part of a national effort to find ways of bringing low-income families up to the national level. ${ }^{2}$ In these experimental counties, officials and organizations in the local community will have the assistance of state and national agencies in a concerted attempt to solve the income problem.

Leadership in the program will remain at the local level. The basic decisions as to what should be done and how it should be done can come only from local people who understand all elements involved in the income situation in their areas.

This publication is designed to assist the people of the area in analyzing their situation. Some of the intangibles, such as the basic goals and interests of the people, family traditions in regard to work and ways of farming, and circumstances and complexes that affect individual habits and attitudes, are not treated. These things are difficult to measure, but they are quite as important as the more measurable factors discussed here. Only those who live in the area can assess the intangibles accurately.

\section{BASIC ECONOMIC FACTS}

\section{This is a marginal area for many types of agriculture}

In most parts of the area the topography is too rugged for farming. According to the census, in 1954, less than a third of the area of approximately $1,000,000$ acres was in farms, and only 42,878 acres, or

${ }^{1}$ Agricultural Economist, Farm Economics Research Division, Agricultural Research Service, U.S. Department of Agriculture, and Agicultural Economist and Professor of Agricultural Economics, West Virginia University, respectively. This study was made in cooperation with the Area Rural Development Committee of Fayette, Raleigh, and Summers counties, West Virginia; the West Virginia Employment Security Commission; and the Bureau of Employment Security, U.S. Department of Labor.

'See Dcvelopment of Agriculture's Human, Resources, United States Department of Agriculture. April 1955. 
4.1 percent, was in crops. Almost half of the farm acreage was in woodland, and of this about a third was pastured. Open pasture land amounted to 99,000 acres and brought the area used for livestock up to approximately 50 percent of the total acreage in farms.

Basic land use figures for the three counites in 1954 were as follows :

\begin{tabular}{|c|c|c|c|}
\hline & Fayette & Raleigh & Summers \\
\hline Total acreage in county & 421,760 & 386,560 & 229,160 \\
\hline Acreage in farms & 70,665 & 105,149 & 141,991 \\
\hline Acreage in crops ........ & 11,192 & 13,914 & 17,767 \\
\hline 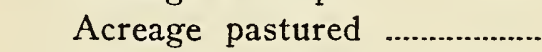 & 25,579 & 46,381 & 76,669 \\
\hline Acreage of unused cropland.. & 6,904 & 18,126 & 7,274 \\
\hline
\end{tabular}

The topography of this area varies from county to county. Both Fayette and Raleigh counties have rough terrain. Agricultural activities are concentrated at the eastern edge where the land flattens out and where the valleys and plateaus are better adapted to farming. The agricultural area extends into Summers County where agriculture constitutes the major basis for economic support.

The soils in the area are also highly variable. Ordinarily, soils in the more rugged sections are too stony and thin to be suitable for growing crops. Often they are so light in texture that they lose moisture quickly in dry weather and are not satisfactory for pasturing. The soils in the valleys and on the rolling plateaus are of better quality, but on most farms the acreage of good land is limited because of the variable topography.

These counties were formerly covered with an excellent stand of timber, and lumbering was a major enterprise. The good timber has been almost entirely cut over but there is still some cutting of secondgrowth trees. As the resources of the area are becoming more limited, belated attention is being given to protecting and building up the forest potentials.

The effects of this meager physical foundation are reflected in the incomes from farms in the area. The 1954 Census of Agriculture showed that the area had 5,140 farms with an average value in land and buildings of about $\$ 6,000$. The total value of sales of farm products from these farms for the year was $\$ 2,116,208$, an average of $\$ 412$ per farm. Only 16 farms had sales of more than $\$ 10,000$; 66 had sales of more than $\$ 2,500$, and 207 had sales of more than $\$ 1,200$.

The fact that the area is marginal for agriculture is most significant in a Rural Development Program. But efforts along this line should not be reduced nor should they be concentrated only on opportunities in other sectors of the local economy. There are families in 
the area who depend upon agriculture partly or wholly for their livelihood. Furthermore, agriculture contributes to a diversified economic base for the area. Instead, the situation calls for more careful planning, an evaluation crop by crop and enterprise by enterprise, to determine what can be produced competitively with other areas. Since the area varies so greatly, the findings for one section might not apply to another. The situation puts a premium on the use of the most efficient methods by individual farmers.

\section{Agriculture is secondary to other lines of economic activity}

The comparative size of the economic base in the three counties is partly reflected in the size of their respective populations-Fayette 82,000 , Raleigh 96,000, and Summers 19,000. The basic difference between the counties is that Summers has no coal deposits. The terrain, however, is less rugged and better suited to agriculture.

The figures in Table 1 provide a general picture of the economic base of the area. In 1954, the value of coal shipments out of the two mining counties was in excess of $\$ 69,000,000$. These counties also led in value added by manufacture. Unfortunately, the manufacturing data are incomplete because figures were not published by the census for the county with the largest plant. An estimate of $\$ 15,000,000$ to $\$ 20,000,000$ for the two counties might be made. In contrast the value of farm products in these counties was $\$ 1,380,000$, or about one-sixtieth of that of mining and manufacturing.

Summers County, however, had no mines and the value added by manufacture was less than the value of farm products. The value of farm products in the three-county area runs slightly above $\$ 2,000,000$ as compared with $\$ 85,000,000$ to $\$ 90,000,000$ in manufacturing and mining.

Bituminous coal mining, then, provides the principal economic basis for the dense population in the area. Also, it has a significant effect on agricultural operations. Of the 5,140 farms in these counties in $1954,4,400$ were part-time or residential. This must be regarded then mainly as a part-time farming area.

\section{The economic base of the community is decreasing}

The economic growth and prosperity of the area has been based on wage and employment levels in the coal industry. (See Table 1 for wages and salaries.) Mechanical mining equipment, however, is being installed in place of hand labor. Mechanization is gradually cutting down the number of pay checks that are spread over the community. New jobs for the clisplaced workers are not available locally, and many 
Table 1. Economic Resource Data, Fayette, Raleigh, and Summers Counties 1954*

MINERAL INDUSTRIES

\begin{tabular}{|c|c|c|c|c|c|}
\hline \multirow[b]{2}{*}{ CotrnTy } & \multirow{2}{*}{$\begin{array}{c}\text { ESTABLISH- } \\
\text { MENTS }\end{array}$} & \multirow{2}{*}{$\begin{array}{l}\text { COAL } \\
\text { MINES }\end{array}$} & \multicolumn{3}{|c|}{ COAL MINING } \\
\hline & & & EMPLOYEES & $\begin{array}{l}\text { WAGES AND } \\
\text { SALARIES }\end{array}$ & $\begin{array}{l}\text { VALUE OF } \\
\text { SHIPNENTS }\end{array}$ \\
\hline & Number & Number & Number & Dollars & Dollars \\
\hline Fayette .......... & 106 & 100 & 4,611 & $19,981,000$ & $33,052,000$ \\
\hline Raleigh ............ & 111 & 103 & 5,171 & $20,770,000$ & $36,317,000$ \\
\hline Summers ........... & 0 & 0 & 0 & 0 & 0 \\
\hline
\end{tabular}

\begin{tabular}{|c|c|c|c|c|}
\hline \multicolumn{5}{|c|}{ MANUFACTURING } \\
\hline \multirow[t]{2}{*}{ COUNTY } & $\begin{array}{l}\text { ESTABLISH- } \\
\text { MENTS }\end{array}$ & EM PLOYEES & $\begin{array}{l}\text { WAGES AND } \\
\text { SALARIES }\end{array}$ & $\begin{array}{l}\text { VALUE ADDED BY } \\
\text { MANUFACTURE }\end{array}$ \\
\hline & Number & Number & Dollars & Dollars \\
\hline Fayette ............. & 37 & 2,205 & $* *$ & $* *$ \\
\hline Raleigh ............ & 52 & 792 & $2,592,000$ & $4,672,000$ \\
\hline Sunmers ........ & 24 & 138 & 291,000 & 428,000 \\
\hline
\end{tabular}

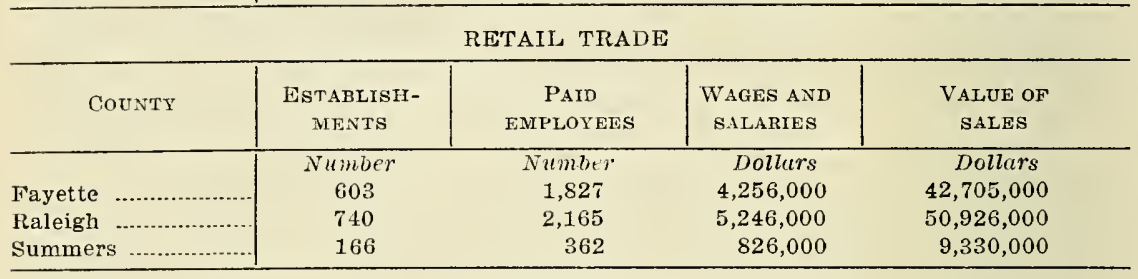

AGRICULTURE

\begin{tabular}{|c|c|c|c|c|c|}
\hline County & FARMS & $\begin{array}{c}\text { FAMILY } \\
\text { WORKERS }\end{array}$ & $\begin{array}{c}\text { HIRED } \\
\text { WORKERS }\end{array}$ & $\begin{array}{c}\text { WAGES } \\
\text { PAID }\end{array}$ & $\begin{array}{l}\text { VALUE OF } \\
\text { SALES }\end{array}$ \\
\hline & Number & Number & Number & Dollars & Dollars \\
\hline Fayette & 1,675 & $1,770 \dagger$ & 45 & 37,260 & 593,514 \\
\hline Raleigh ................ & 2,038 & 2,467 & 60 & 69,755 & 788,818 \\
\hline Summers ......... & 1,427 & 1,669 & 164 & 80,023 & 733,876 \\
\hline
\end{tabular}

*From Census of Mineral Industries, Manufacturers, Business, and Agriculture respectively, 1954.

**Data not given so as not to reveal data for one establishment. Figures for this county are much higher than for the other two.

$\dagger$ Includes the farm operator.

workers who have looked for jobs elsewhere have come back still unemployed. Many of the miners have only the one skill, and the market for this skill is declining at varying rates in all coal areas.

A miner's unemployment compensation check is likely to amount to $\$ 25$ a week; these checks help to keep the stores in the community open. But many workers have exhausted their unemployment benefits and are resorting to public assistance. Figures for March 1959 indicate that 22,776 people were receiving surplus commodities in Fayette County during that month-24,835 in Raleigh County, and 3,376 in Summers County."

${ }^{8}$ Data from Surplus Food Distribution Branch, United States Department of Agriculture. 
Many of the miners will be obliged to leave the area unless new industries and jobs are brought into it. The employment phase of the Rural Development Program calls for immediate action.

\section{Most households in the open country have no relationship to agri- culture}

The usual idea that families living in the open country are farm families is far from true in the Beckley area. The survey made in 1958 provides an indication of the types of open-country households in Fayette, Raleigh, and Summers counties:

\section{Type of household}

All open-country households in sample

Nonfarm (no agricultural activity)

Farm (some agricultural activity)

All income is from farming

Farming is major source of income

Farming is minor source of income

\section{Number Percent}

1,149

100

$852 \quad 74$

$297 \quad 26$

$41 \quad 4$

494

$207 \quad 18$

Most open-country homes are lined up along the major roads and highways in "stringtown" fashion. Ordinarily, they are the homes of nonfarm workers. Some have small acreages which are not farmed, but which provide "elbow room" and other advantages of country living.

Three-fourths of the families living in the open country did no farming. Less than 4 percent lived by agriculture alone. The other 22 percent combined agriculture with other sources of livelihood.

This may mean that a considerable amount of good farmland is not used for agricultural production. A special examination of this situation may be needed. If much good land is not being utilized, some program to encourage rental of this land to farmers might be practicable.

\section{Most "farm" households have farming as a sideline}

On the basis of sources of income, the farm households in the area can be classified as follows:

Source of income

All farm households in sample

All income from agriculture

Income from agriculture and nonfarm work ....

Income from agriculture and nonwork sources..

Income from agriculture, noniarm work, and nonwork sources
Number Percent

297

100

$41 \quad 14$

$85 \quad 29$

$83 \quad 28$

S8 
Only one in seven households had income from agriculture alone. Although all had some interest in agriculture, 58 percent had someone in the household with nonfarm employment. Of these households, 57 percent had some member with an income from social security, retirement funds, or other "nonwork" sources. Twenty-nine percent of farm households had income from all three of these types of sources. Two-thirds of the farm households had the major source of their income outside agriculture.

This diversified income situation may help to provide some measure of economic security. It also means a group of people with diverse interests, and a type of community that will call for a speciallyplanned effort on the part of Rural Development Committees.

The fact that most farmers have an outside source of income, usually larger than that from the farm, affects an agricultural development program. These farmers are not dependent on the efficiency of their agricultural enterprise. The added returns they might obtain from additional effort may be well below their regular pay scale. But the Rural Development Program may not be directly concerned with these farmers unless they are still in the low-income group.

\section{Open-country families in Summers County are more agricultural than those in Fayette and Raleigh}

A different type of economy exists in Summers County, so the three counties cannot be regarded as having the same type of economic problem. The open-country households there are more often engaged in farming. The sample for the 1958 survey indicated the frequency of open-country households that did some farming to be as follows:

\section{County}

Type of open-country household Fayette Raleigh Summers Farm (some agricultural activity) ....... 82 Nonfarm (no agricultural activity) ....... 292

94

476
121

53

Furthermore, the farming is more often the major activity than in the other two counties.

These differences call for a different emphasis on Rural Development plans for Summers County. An increase in income levels is needed. The potentials for agricultural expansion are greater but fewer people are trained in industrial, managerial, and office techniques than in the other two connties.

7. Farm households have more children and youth and fewer people of working age than the normal farm population composition

Migration of young people from the farm households in the area has occurred to such an extent that the percentage of people aged 25 
to 34 , the best working years, is 34 percent as compared with 39 percent for the Nation generally. But the percentage of youth aged 14 to to 24 is higher. The percentages of the different age groups in the area and the United States are as follows:

55 and

Under $14 \quad 14$ to $24 \quad 25$ to $54 \quad$ over

$\begin{array}{lllll}\text { Fayette-Raleigh-Summers ........ } & 30 & 17 & 34 & 19\end{array}$

United States …......................... $30 \quad 14 \quad 39 \quad 17$

Apparently, employment outlets for young people are not as good as they might be. They are obliged to compete against displaced workers with families, hence must delay setting out for themselves.

The greatest youth problem lies in families in which there is a nonfarm worker. Comparative age groupings according to source of income is as follows:

Percentage in each age group

55 and

Source of income

Under 1414 to 2425 to 54 over

Agriculture only 14 31

23

Agriculture and nonwork sources .... 19

14

25

42

Agriculture and nonfarm work

34

18

41

7

Agriculture, nonfarm work, and

nonwork

31

20

34

15

Families with some nonfarm income are younger than the strictly farm families. They face the most difficult problem in getting their youth started in the world.

8. Members of farm households have serious educational deficiencies

The farm people in the three-county area are handicapped because of limited education. Many ended their schooling at the grade-school level, and the shift toward more education has not kept pace with that in the Nation generally. Comparative figures on educational attainment of the young adults in the area and in the United States are as follows :

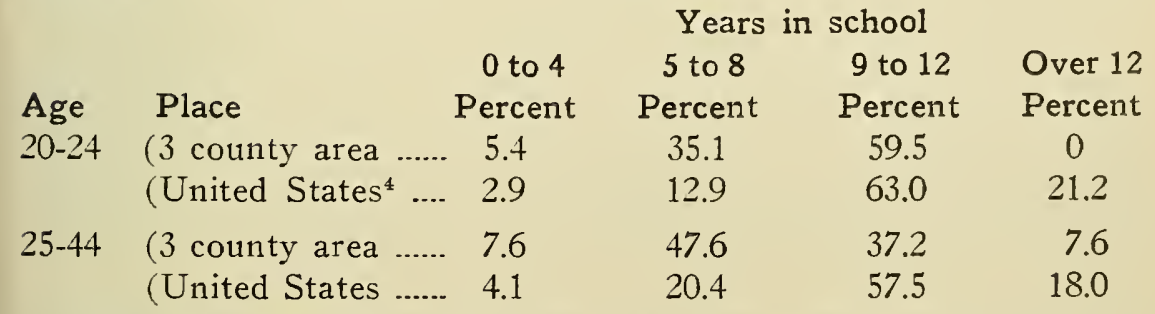

${ }^{4}$ Data from Educational Attainment, March 1957, United States Bureau of the Census, December 1957. 
This comparison is affected by the fact that the youths with more education have left the farm, and that those who remained did not foresee the need for extensive training.

Very few reported any special vocational training.

Instead of education and training, these young adults have had work experience in a combination of agriculture, coal mining, and other unskilled or semiskilled jobs. But the heavy demand in industry and business is for workers with at least a high school and preferably a college education, or with some special technical training or experience.

\section{DEVELOPMENT PROGRAMS}

1. A concerted effort in regard to agricultural development is already underway in the area

Some civic leaders in the Beckley area have been working to develop more than a one-industry economy. Their efforts have been directed toward: (1) developing agriculture to the fullest extent, (2) encouraging manufacturing concerns to locate in the area, (3) building up the recreational possibilities, and (4) inducing civic, educational, and other organizations to establish headquarters in the area. The wisdom of this approach has become apparent now that employment in the mines has decreased.

The most careful planning has been done in the field of agricultural development. In 1948, the Doane Agricultural Service was asked to survey the agricultural resources of the area and make recommendations for their development. ${ }^{5}$ The service recommended a coordinated town and county program that would be supervised by a Community Development Council. This recommendation was put into effect and the Beckley Area Rural Development Council has functioned since that time.

The specific recommendations made by the Doane Agricultural Service included primary emphasis (1) on dairy cattle, which called for better pastures, higher producing cows, better hay and silage, and better barns; (2) on beef cattle and other livestock, especially for the eastern part of the area; (3) on poultry, including production of broilers and eggs. To these major recommendations should be added (4) production of fruits and vegetables for local use; (5) systematic production and marketing of trees as a crop; and (6) encouragement of a part-time farming program for industrial workers.

'See Beckley Area Rural Conmunity Development Plan. Doane Agricultural Serrice, St. Louis, 1949 . 
These recommendations were designed to fit an area of limited soil resources and one of part-time farm operators. Following this survey, the Beckley Area Rural Development Council was established and a capable manager was employed to put the program into effect. Marketing experts were asked to appraise the feasibility of setting up a farmers' wholesale market. They advised against construction of such a facility on the grounds that (1) an insufficient volume of local produce was available, and (2) existing food-distribution facilities were adequate and did not involve construction of such a market. ${ }^{6}$

The success of part of the Doane progran, however, depended on the existence of such a market facility. So the market was constructed and has since been struggling to obtain a role in the local agricultural economy. There has been an active program to increase the volume of local products to justify the existence of a separate market. Local food handlers, however, have not gone out of their way to try to handle local products. They have found it more satisfactory to deal with their regular suppliers than to cater to local producers.

This situation is a barrier to the efforts of local producers to produce fruit, vegetables, milk, eggs, and meat for local consumption. With such a large local market available, farmers find it difficult to understand why preference should be given to outside suppliers.

\section{The present Rural Development Program is an outgrowth of these efforts}

The Beckley Area Rural Development Council proposed that the three counties be accepted as a pilot area under the nation-wide Rural Development Program. This would bring additional leadership and resources to bear on the income problem in the area. This proposal was accepted by State and Federal Rural Development officials.

The emphasis in the new program will be focused to a greater extent on rural people than on agriculture. The economic adjustment of families and individuals will be the primary goal. Some low-income families with poor prospects in agriculture may be encouraged to go into nonfarm employment. Low-income nonfarm families may be encouraged to take up new lines of employment. The new program will also emphasize general economic development of the local area, but as a means toward income improvement of low-income households.

The 10 years of concerted effort by the Rural Development Council have provided a foundation for an even more intensive program. Some of the major gains of the existing program can be listed as follows: (1) Development of an informed local leadership; (2) the setting up of working relationships between agricultural and other agencies;

${ }^{6}$ Wholesale Marketing of Produce in the Beckley, West.Virginia Area, by T. D. Johnson and Homer Evans. United States Department of Agriculture, 1952. 
(3) establishment of some measure of community awareness and acceptance of a Rural Development Program; (4) much experimenting and testing of crops, enterprises, and methods carried out; and (5) the building of a real foundation for the egg, broiler, and dairy enterprises.

\section{Present community circumstances are more favorable for a con- certed program than they have been in the past}

Several years ago most sectors of the local economy were so prosperous that no type of development program was taken very seriously. It was felt that any man or any sector of the economy that were in difficulty were in the wrong line of work and needed to try something else. Now, through no fault of its own, a whole community may be in the wrong line, and people are more willing than formerly to talk adjustment or development.

Previously, nonfarm earnings were so high and so dependable that the returns from a garden, poultry, or dairy looked very small compared with the work involved. Few agricultural producers felt the need to pool their efforts in order to obtain maximum production, standardized products, and local market facilities. Nonfarm workers and part-time farmers are now realizing that the economy will not carry them along without some effort on their part.

The economic climate in the area has changed. Today, because of the change, a program to encourage consumers to give preference to local products is more likely to succeed. Businessmen, too, are more likely to see some gain from pushing the sale of locally grown produce. Farmers, and particularly part-time farmers, are more likely to see some advantage in diversifying their efforts.

\section{The efforts of these two development agencies are to be supple- mented by those of an Area Development Program}

During the last year, industrial and commercial interests in the area have been stimulated into organizing an Area Development Program. This was initiated originally by the electric power companies servicing the area and is designed to attract outside industries. It emphasizes zoning and community planning in order to establish industrial sites, residential sites, schools, and other facilities that would be required by an industrial and managerial population. This effort should provide an effective supplement to the other development programs.

5. Survey data indicate that the area has made significant progress along agricultural lines

Agricultural development in the area has been away from cominercial crops that depend directly on soil fertility and in the direction 
of poultry, eggs, and dairy products that call for skilled labor. It is also in the direction of intensive use of the small acreages that are available. Survey data in 1958 indicate that more than 60 percent of the gross farm income in the three counties came from poultry and eggs. ${ }^{7}$ Another 30 percent was from dairy products and livestock sales. The value of crops sold came to slightly above 8 percent.

The area has already made substantial progress toward specialized commercial agriculture. Farmers here are in better shape for commercial competition than those in most agricultural areas. Although some farmers have made no attempt to modernize their operations, the present nucleus of progressive farmers can help to transform the agriculture of the area.

\section{THE LOW-INCOME PROBLEM}

1. Low incomes are associated with farming and with nonwork sources

Of the 297 farm households, 45 , or 15 percent, had incomes of less than $\$ 1,000$. Of the households with incomes of less than $\$ 1,000$, 28 had all their income from agriculture; all except two of the remaining families in this income bracket depended upon agriculture plus some type of "nonwork" payment such as social security, retirement pay, or old age assistance.

The number of households according to sources of income was as follows :

Amount of income

Income sources Under $\$ 1,000-$ Over $\$ 1,000 \quad 2,999$ $\$ 3,000$

All from agriculture 28

Agriculture and nonfarm work 13 Agriculture and nonwork sources .... 17 68

$15 \quad 56$
Agriculture, nonfarm work, and

and nonwork sources

All except 2 of the 41 households that depended on agriculture alone had incomes of less than $\$ 2,000$. Low incomes, therefore, are associated with agriculture. These families are the focal points for special attention in a Rural Development Program.

'See first report in regard to the Fayette, Summers, Raleigh counties Rural Development Program, Farming, Farm People, and Farm Expansion, Fayette, Raleigh, and Summers Counties, 1958, by William $H$. Nretzler and W. W. Armentrout, West Virgiuia University Agricultural Experiment Station. 
2. Nonwork sources (social security, public assistance, unemployment insurance, etc.) plus agriculture, however, provide a much sounder economic basis for the household than agriculture alone Of the 297 farm households, 83 had income from nonwork sources as well as from agriculture. With only a few exceptions, these families were in a higher income bracket than those that relied on farming alone. Two-thirds of them came in the income bracket of $\$ 1,000$ to $\$ 3,000$.

The comparative income situation of these households was as follows :

Number of households with income

Type of household Under $\$ 1,000$ to $\$ 3,000$ Agriculture only $\$ 1,000$ 2,999 and over Agriculture and nonwork sources 28 15 13 56

These households are made up largely of aged people, retirees, and public assistance cases; ordinarily, they are not the best suited people for a farm expansion program. Ordinarily, also, they have adjusted their scale of expenditures to their monthly payments and are living comfortably. They supplement this income with small sales of farm products and some production for home use.

3. Incomes from nonfarm work dwarf those from agriculture and nonwork sources

There were, then, 124 households that had no connection with nonfarm employment. In terms of cash income, they were in a poor position compared with households that had some nonfarm work income.

Number of households with income Under $\$ 1,000$ to $\$ 3,000$

Type of household $\$ 1,000$ 2,999 and over No nonfarm work 43

With nonfarm work 2 69 38

133

The household with an employed nonfarm worker is practically always outside the low-income group. It is only when the worker is unemployed that the household drops into the low-income group.

4. Unemployment of the industrial worker is the most serious blow to the local economy ${ }^{8}$

Since industrial workers have been highly paid in recent years, an economic structure of merchants, professional people, and other

\footnotetext{
${ }^{8}$ The third report in this series will deal especially with the problem of industrial employment and industrial expansion in this area.
} 
service agencies has been developed in the area to meet their needs. Now that these workers have much less to spend, the service agencies are badly hurt. In turn, their losses have an impact on other agencies in the community.

The low-income farmers, however, have not had sufficient spending power to build up an extensive commercial and professional structure to meet their needs.

From a community standpoint, therefore, the most pressing problem is to rebuild the industrial structure and create employment for local workers who have been displaced by machines and technical change in sources of fuel. Displaced workers constitute a resource that is not now utilized and which will need to go elsewhere if it is not put to use soon. There is an urgency about this phase of the problem that calls for quick action and planning. Some of the other phases can be handled in long-range programs.

\section{ELEMENTS IN A SOLUTION}

1. A significant proportion of the younger farmers in the area would like to expand their farming operations

Only farmers under 50 years of age were asked about their desire to expand farm operations. Almost half, 42 percent, were interested, and their greatest desire was to increase their livestock operations, including poultry. Most of those who said they wanted to expand their operations had their major source of income outside agriculture.

Source of income

Agriculture Agriculture Agriculture

Farmers under 50

years of age

Total

only

major source minor source

Interested in

10

94

expanding their

farms

50

Willing to borrow in order to do so.

Who have thought of going out of farming

Who have thought of leaving the area 
Many of the younger farm operators in the area, therefore, are interested in building up or improving their farming operations. Agricultural expansion depends largely on giving them an opportunity to put their desires into operation, within the limits of available land resources and potential markets.

\section{Low-income farmers lack the desire to build up their farming enterprises}

With only eight exceptions, the farmers interested in expanding their operations were not in the low-income group. Their average total incomes were about $\$ 4,000$ and their average net income from agriculture was about $\$ 1,300$.

Income from agriculture Under $\$ 1,000 \quad \$ 1,000$ and over

All farmers in sample 177

Those under 50 years old 67 120

Those who desire to expand

The lowest-income people, therefore, are not among these more ambitious farmers. The usual agricultural program may reach the more prosperous farmers and expand the community income, but it is not likely to be effective with the low-income households. Apparently, a specially-designed program is needed to identify the lowincome families and to analyze their income problems.

\section{As farmers see it, the greatest obstacle to expansion of farm enter- prises is lack of capital}

Inability to obtain credit is the most frequently mentioned barrier to farm expansion: 39 to 50 farmers who desired to expand said that lack of capital was their major obstacle. Most of the changes the farmers wished to make called for an investment of several thousand dollars. They contended that there was no public agency to meet their needs, and that regular bank rates were too high. They also reported that Federal loan programs usually had requirements or restrictions that prevented them from qualifying for loans.

The Farmers Home Administration of the U.S. Department of Agriculture has recently revised its eligibility requirements for operating and farm ownership loans. Now, farmers in Rural Development counties who are regularly employed off the farm, if they meet other eligibility requirements, may obtain credit assistance from Farmers Home Administration. Previously, a farmer had to spend most of his time farming in order to qualify for a loan. 
4. It is probable that most of the low-income families will not respond readily to an agricultural program

The farmers who had no desire to improve their farm businesses generally mentioned one or more of the complex of reasons for not doing so:

1. Have other and more profitable employment.

2. Have no interest in farming.

3. As there is no money in farming, any extra effort will be a waste of time.

Of the 68 farmers who did not wish to expand, 55 gave one or more of these three foregoing reasons. These farmers are poor prospects for a farm program in which quick results are needed. Three more were poor prospects because of illness. Six did not wish to expand because their farms were on poor soil or because of the scarcity of farm labor.

Apparently, lack of interest in farm expansion comes from the belief that, compared with other lines of activity, farming involves much work for a very small return. The truth of this belief is particularly apparent when farm returns are compared with the wages earned in mining. Only a few of the most skilled farmers can do as well as the miners. Overcoming this attitude will require a great deal more than a promotional campaign.

\section{Most people still in farming wish to stay}

One in six farmers in the survey had given some thought to going out of farming. Most of these, 19 out of 20, were small part-time or subsistence farmers who already had some nonfarm employment. None of them was in the under $\$ 1,000$ income bracket.

Apparently, most of the people who have wished to get out of farming have already done so. The years of urban and industrial expansion have already pulled them in to other lines of work. The hard core that is left want to stay in agriculture if they can. An attempt to persuade established farm people to move from the land would seem to be unfruitful. This applies to the heads of the families. The children and youth might have a different reaction.

\section{Relatively few of the farm people wish to leave the area}

One in seven farmers had thought of leaving the area, and most of those who had done so had agriculture as a sideline. These who had done so were not in the lowest income bracket. Again, it appears that there is a hard core of farm people who wish to stay where they are. This finding again applies to the head of the household; the children were not questioned as to their preferences. 
7. The low-income farm people, therefore, want to stay where they are and continue to combine small-scale farming with nonfarm work

Apparently, these people have not been infected with the desire for bigness, efficiency, and profit-making enterprises. They seem to have the economic values of prior generations of hill folk, who were unconcerned about the dangers of competition and loss of markets. So long as such people can continue in noncompetitive subsistence agriculture and obtain some nonfarm employment, they may not be in a bad economic position. But now there is some question as to their opportunities to find nonfarm work. The reduction in employment in coal mining may serve to remind them that they have entered the competitive economy, even though they may have wished to stay out of it.

To reeducate these people will take time. It may be easier to start with the youth and children than to devote too much time to the adults. But it must be remembered that young people who are raised in these values wili not shift automatically to another way of life.

Also, it may be easier for these people to shift into nonfarm employment than into the management of large efficient farm enterprises. The former calls for learning a limited range of skills and for some minor changes in rural values; the latter calls for a major reorientation in regard to agriculture and managerial enterprise, which may take several generations.

A program of career exploration for the young people in these households can help them decide which occupation they should follow. Those who decide to remain in agriculture will require special training.

8. What, then, are the lines of rural development that will fit in with the interests and potentials of the people in the area?

First, increased agricultural activity, but not on the part of the people at the lowest income level. These people show little interest in agricultural expansion. The others need improved sources of credit. Second, training of young adults, and particularly of children and youth, in nonfarm skills. A special program of career exploration and guidance for youth for low-income households. Third, increased effort toward industrial expansion. The interests and experience of the present population are in the field of industry and other nonfarm employment rather than in agriculture. Local industrial expansion is desirable because most people have a strong attachment to the local area. They are likely to be better adjusted citizens and workers in this area than in strange surroundings. 
9. Data are becoming available as to the most effective ways of achieving sound industrial expansion

Studies made in rural development areas in the United States are beginning to supply some information in regard to methods of local industrial expansion. These studies indicate that one of the surest ways to bring this about is to get existing local factories to expand their operations. Many plants are not used to their full capacity. A second method is to analyze the distribution of locally produced raw materials to ascertain whether it is feasible to process them at home. A third is to examine local consumption habits and ascertain whether any of the products used can be processed locally. Then local plants can add new lines of production or new plants can be promoted.

These methods offer more possibilities than does the obtaining of new factories or branch units for the local area, although the latter method merits close attention. Many industrial concerns that wish to expand are checking over areas that have potential labor supplies.

Important elements for industrial expansion in the Beckley area are present. These include local capital and managerial ability and an adequate labor supply. Local planning and consultation with industrial experts could bring results.

\section{Present agricultural programs could be intensified}

Economists at West Virginia University have been charting the trends in agricultural development in the State. These trends indicate a pronounced decline in crop production and movement toward a livestock economy. Greatest gains have been in production of dairy products, eggs, broilers, and turkeys. For this reason, present programs should be continued and intensified. Even though the program is directed toward the more prosperous farmers, it will benefit indirectly all elements in the community.

The credit problem calls for concerted action either to liberalize credit policies of existing public and private organizations or to establish credit associations that will meet the farmers' needs. Another potential source of credit is through feed dealers and produce buyers. 'This system of credit is especially well adapted to broiler production, but it can be applied to other types of livestock enterprises. It can be used to provide excellent first-hand training in efficient management and low-cost production.

As good potential farmers in the low-income group are identified, they should be given special attention in order to bring them up to the level of other farmers. This is a selective process. 


\section{Vocational training is a relatively new approach to this problem and will call for a pioneering effort}

Some vocational training has been part of the regular school curriculum in this area for some years. A private college at Beckley has been doing an excellent job in training for business careers. But a vocational retraining program on the scale needed in the area calls for facilities and an organization that are far beyond those now in existence. Youth and young adults need to be trained in the skills that are required in industrial establishments. The existence of a trained labor supply would not only assist local concerns to expand but also would attract outside firms to the area.

When a displaced coal miner registers for unemployment compensation, he could be given the opportunity to enroll in a vocational training course. Those who are already on the unemployment insurance rolls and those who have exhausted their benefits could be urged to start a retraining program as soon as possible. Only in this way can modern technology, family responsibility, and community integrity proceed together.

At the same time, the regular school program can be reoriented to help solve the economic problem in the area. Industrial and trade training courses can be made a part of the high school curriculum. A night school emphasizing vocational courses should be available for young people and workers who desire retraining.

The equipment needed for vocational courses is expensive. Yet investments along this line are investments in resources for the community in the future. There are too few trained young people to meet the demand. Factory managers are as much inclined to move their factories to an area with efficient labor as to try to draw the labor away from the area.

Improvement of the industrial skills of the labor force is likely to be the most difficult phase of a Rural Development Program because of the lack of established agencies to do the job. It calls for a pioneering effort to set up a program that can make the manpower of the area useful again. Local school and Employment Service officials can supply basic information about lines of organization and activity. Use of existing training facilities can be expanded, and new ones can be developed.

The youth in low-income farm households will need a program of career exploration and guidance. Ordinarily, they have less opportunity than others to observe and examine either nonfarm occupations or the activities and responsibilities of the successful farm operator. 
Many of the people who have special training may leave the community, but there is a strong tendency for people to remain in the area as long as they can. Consequently, if the industrial and commercial leaders can expand local employment opportunities, they need have little fear that any large number will leave. A well-planned training program, plus an industrial expansion program, offers the surest path to increased income for both the workers and the community.

12. This community has an opportunity to become a leader in the Rural Development Program

Rural development in this area is manysided. It involves the entire economic structure of the community-mining, manufacturing, business, the professions, and agriculture. It has both short- and long-range aspects. The need for immediate action creates an urgency that does not exist in many of the experimental areas over the United States. The area has had 10 years of successful background in planned agricultural and commercial programs. These provide an impetus that can be used to advantage. This community, therefore, has a potential to move forward much more rapidly than most areas. It should be able to set many patterns that could be useful in other rural development areas, and at the same time to meet its own problems. 


